\title{
Analisis Perbandingan Kinerja Ekualisasi Zero Forcing dan MMSE pada FBMC-OQAM
}

\author{
JANS HENDRY, ANGGUN FITRIAN ISNAWATI
}

\author{
Institut Teknologi Telkom Purwokerto \\ Email: jans@ittelkom-pwt.ac.id
}

Received 11 Mei 2019 | Revised 7 Juli 2019 | Accepted 19 September 2019

\begin{abstract}
ABSTRAK
Kebutuhan layanan data pada teknologi $5 G$ sangatlah tinggi. FBMC sebagai solusi dari kelemahan yang ada di OFDM menjadi teknologi yang digunakan pada komunikasi 5G. Pada OFDM, penggunaan ekualisasi sudah sangat banyak dilakukan penelitiannya dan menunjukkan hasil yang bervariasi tergantung dari jenis ekualisasi yang digunakan. Beberapa jenis ekualisasi yang digunakan pada modulasi OFDM antara lain Zero Forcing dan MMSE. Pada penelitian ini, beberapa variasi ekualisasi tersebut diterapkan pada $F B M C$ dan dianalisis perbandingan kinerjanya. Penggunaan modulasi Offset-QAM yang dipadukan dengan FBMC mempunyai fungsi sebagaimana cyclic prefix pada OFDM (CP-OFDM) yakni untuk mengurangi inter symbol interference (ISI). Hasilnya menunjukkan bahwa nilai BER pada FBMC yang menggunakan ekualisasi MMSE pada SNR 5 dB mempunyai nilai sebesar 0,2941 sedangkan BER pada FBMC yang menggunakan ekualisasi ZF sebesar 0,2875. Nilai SER untuk ZF sebesar 0,5514 dan untuk MMSE sebesar 0,5391. Kapasitas kanal Hal ini menunjukkan bahwa kinerja FBMC dengan menggunakan ekualisasi MMSE lebih baik dibanding Zero Forcing.
\end{abstract}

Kata kunci: FBMC, Offset-QAM, ekualisasi, Zero Forcing, MMSE

\begin{abstract}
The needs of data service on $5 G$ technology is extremely necessary. FBMC as a solution over OFDM's drawbacks becomes the technology that is used in 5G communication. In OFDM technology, various equalisation methods have been used and final result highly depends on which method being used. Some of equalisation methods used in OFDM modulation are Zero Forcing (ZF) and MMSE. In this research, those equalisation methods were used on FBMC modulation and the performances were analyzed. The use of Offset-QAM modulation combined with FBMC actually functioning like Cyclic Prefix on OFDM which is to reduce Inter Symbol Interference (ISI). The result shows that BER value on FBMC that used MMSE equalisation when SNR $5 \mathrm{~dB}$ equals to 0.2941 whereas BER value on FBMC that used ZF equals to 0.2875. The value of SER on ZF is 0.5514 and MMSE is 0.5391 . Channel Capacity calculation also shows that FBMC performance with MMSE is better than Zero Forcing.
\end{abstract}

Keywords: FBMC, Offset-QAM, equalization, Zero Forcing, MMSE 


\section{PENDAHULUAN}

Orthogonal Frequency Division Multiplexing (OFDM) adalah teknik pentransmisian data berkecepatan tinggi dengan menggunakan beberapa sinyal pembawa (carrier) secara paralel dalam pemodulasiannya. Pada dasarnya frekuensi sub pembawa pada OFDM saling tumpang tindih (overlapping), hal tersebut bertujuan untuk menghemat bandwidth kanal serta meningkatkan kapasitas kanal. Namun OFDM memiliki beberapa kelemahan antara lain keterbatasan yang dimiliki OFDM yaitu sistem yang sensitif terhadap carrier frequency offset, mudah terkontaminasi oleh distorsi linier, serta sulitnya mengoperasikan Fast Fourier Transform (FFT) pada saat sinyal sampai di stasiun penerima. Karena kekurangan yang dimiliki OFDM tersebut, ke depannya untuk memperbaiki kinerja OFDM agar lebih maksimal ditawarkan metode baru yakni Filter Bank Multi Carrier-Offset Quadrature Amplitude Modulation (FBMC-Offset QAM) untuk dapat menghemat bandwidth (Kaur, Kansal, Gaba, \& Safarov, 2018).

OFDM merupakan skema multicarrier paling dikenal sampai saat ini dan juga yang paling banyak digunakan dalam standar saat ini untuk komunikasi nirkabel. Tetapi konsep modulasi multicarrier OFDM dapat diperluas ke sistem yang disebut Filter Bank Multi Carrier (FBMC) (Siohan, Siclet, \& Lacaille, 2002). OFDM pada dasarnya adalah implementasi khusus dari sistem FBMC, dan untuk menghapus blok yang tumpang tindih pada penerima, blok data OFDM biasanya akan didahului oleh Guard Interval (GI), yang disebut Cyclic Prefix (CP) (Baltar \& Nossek, 2012).

FBMC membutuhkan ortogonalitas hanya untuk sub-channel tetangga saja. OFDM mengeksploitasi bandwidth frekuensi yang telah diberikan kepada sejumlah operator, sementara FBMC membagi saluran transmisi yang terkait dengan bandwidth dan kemudian diberikan ke sejumlah sub-channel. Modulasi digital yang digunakan untuk membantu teknik pentransmisian biasanya menggunakan Quadrature Amplitude Modulation (QAM). Modulasi QAM memiliki kelebihan yaitu efisien dalam pemakaian bandwidth dibandingkan dengan modulasi lainnya. Namun QAM juga memiliki kekurangan yaitu decision yang rumit dan memiliki bit rate yang rendah. Untuk mengatasi kelemahan yang dimiliki modulasi QAM kemudian modulasi QAM dikembangkan menjadi modulasi Offset-QAM (O-QAM) yang memiliki kestabilan sistem lebih baik dari QAM biasa yaitu kuat terhadap efek dispersi serta mampu memperbaiki proses decision dan memiliki bit rate yang tinggi. OFDM/O-QAM lebih baik dibanding CP-OFDM dalam BER, hal ini menunjukkan bahwasanya O-QAM memiliki kestabilan yang baik (Blel \& Bouallegue, 2015). Kombinasi spektral dan inefisiensi daya OFDM/QAM dan keuntungan terkait dari Format OFDM/O-QAM berlaku juga untuk kasus dengan jumlah sub-channel yang berbeda. Keuntungan dari OFDM/O-QAM dibanding OFDM/QAM hanya dapat dicapai untuk jumlah sub-channe/ yang lebih kecil dari channe/sebelumnya (Nedic \& Vallet, 2010).

FBMC adalah modifikasi dari pembagian frekuensi orthogonal (OFDM). Dalam OFDM, cyclic prefix digunakan untuk ketahanan sinyal. Ini adalah teknik modulasi untuk mengatasi Inter Symbol Interference (ISI) dan Inter Carrier Interference (ICI). Gangguan inter simbol merupakan tantangan besar dalam sistem jaringan. Pada FBMC tidak perlu menggunakan cyclic prefix untuk mengatasi ISI dan ICI tanpa menambah bandwidth (Kaur et al., 2018).

Meskipun Sistem OFDM memiliki banyak keuntungan: pengurangan ISI, peningkatan kapasitas dan mudah diintegrasikan dengan beberapa antena di kedua sisi pengirim dan penerima tetapi penyisipan cyclic prefix $(\mathrm{CP})$, side lobe yang besar dan nilai PAPR mengurangi efisiensi Sistem OFDM. Misalnya dalam sistem komunikasi seluler $4 \mathrm{G}$, dengan bandwidth operasi $10 \mathrm{MHz}, 7 \%$ bandwidth hilang karena cyclic prefix $(\mathrm{CP})$. Oleh karena itu, FBMC adalah skema modulasi yang 
paling menjanjikan untuk sistem komunikasi seluler 5G karena tidak menggunakan CP dan tanpa membuang bandwidth, efisiensi FBMC sangat ditingkatkan dibandingkan dengan OFDM. Dalam penelitian ini filter prototipe untuk FBMC dan OFDM dirancang dan hasilnya menunjukkan bahwa FBMC mengungguli OFDM sehingga direkomendasikan pada sistem komunikasi 5G (Kansal \& Shankhwar, 2017; Kumar \& Gupta, 2015). Selain itu, rekomendasi tersebut juga dikarenakan FBMC dapat menawarkan kapasitas tinggi (Medjahdi et al., 2009).

Dalam pengiriman sinyal, sinyal yang diterima pada antena penerima pasti tidak akan sama dengan sinyal yang dikirim oleh antena pengirim. Hal tersebut dikarenakan sinyal yang diterima oleh antena penerima sudah bercampur dengan derau (noise). Oleh karena itu dibutuhkan proses ekualisasi untuk dapat mendeteksi sinyal asli yang dikirimkan oleh antena pengirim. Terdapat beberapa algoritma ekualisasi dan Zero Forcing (ZF) banyak dipilih sebagai metode untuk mendeteksi symbo/karena selain dapat meningkatkan kualitas BER, prosesnya pun paling sederhana daripada sistem deteksi simbol yang lainnya (Hidayat, Isnawati, \& Setiyanto, 2011). Ekualisasi jenis lain yang juga banyak digunakan adalah Minimum Square Square Error (MMSE). Oleh karena itu, pada penelitian ini dua variasi ekualisasi tersebut dipadukan dengan metode FBMC.

\section{METODOLOGI}

\subsection{Pemodelan Sistem}

Sebagai tahap awal penelitian ini adalah merancang pemodelan sistem sebagaimana terlihat pada Gambar 1 berikut. Pemodelan ini juga mengacu pada parameter-parameter simulasi yang ditentukan berdasarkan acuan implementasi sistem seperti jenis inputan yang diberikan, penggunaan jenis mapper, penentuan jenis filter, penggunaan channel dan derau serta algoritma ekualisasi yang akan digunakan. Proses pengujian simulasi dilakukan dengan membandingkan hasil simulasi dengan variasi jenis ekualisasi dan dengan hasil teori yang ada, sehingga dari informasi tersebut kemudian dilakukan analisis. Parameter hasil simulasi yang akan diuji meliputi: bit error rate (BER), symbol error rate (SER) dan kapasitas kanal berdasarkan parameter signal to noise ratio(SNR) yang ada untuk setiap jenis ekualisasi yang digunakan yakni Zero Forcing (ZF) dan MMSE.

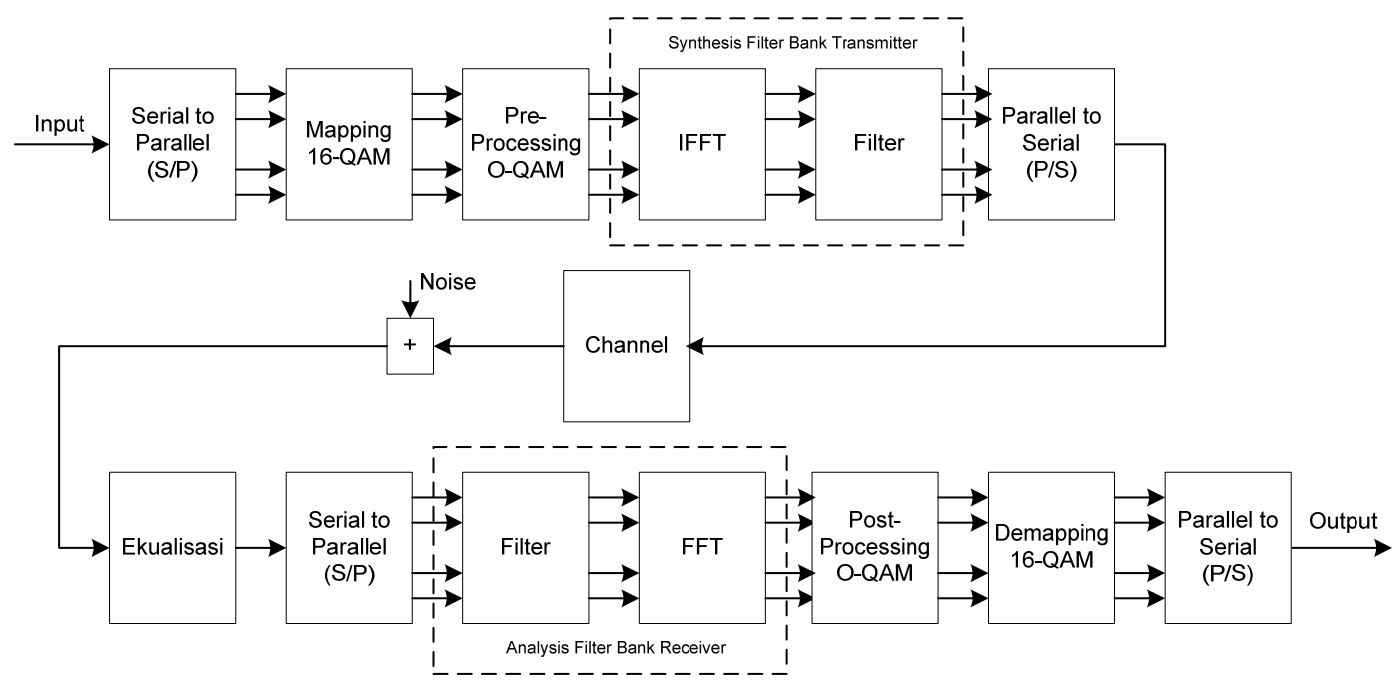

Gambar 1. Pemodelan Sistem FBMC-Offset QAM dengan Variasi Ekualisasi 
Input yang digunakan dalam simulasi ini adalah sinyal audio berekstensi *.wav dengan amplitudo yang telah ternormalisasi dari -1 volt -1 volt dan tanpa offset (zero mean). Agar bisa ditransmisikan, maka sinyal diubah ke dalam deretan bilangan biner (0 dan 1). Pengubahan dilakukan dengan langkah - langkah yang ditunjukkan oleh ekspresi matematis berikut ini:

$$
\begin{aligned}
& V_{1}=V_{0}+1 \\
& V_{t}=V_{1} * 2^{\text {nbit-1}} \\
& B=\operatorname{binary}\left(V_{t}\right)
\end{aligned}
$$

Dengan $V_{0}$ adalah sinyal audio asli, $\mathrm{V}_{1}$ adalah sinyal audio bernilai positif karena sudah ditambahkan dengan nilai 1 . Lalu variabel $n$ bit adalah level kuantisasi sinyal, dan $\mathrm{V}_{\mathrm{t}}$ adalah sinyal audio yang diubah ke dalam format bilangan decimal dengan nbit merupakan level kuantisasinya. Pada Persamaan (3), binary melambangkan operasi pengubahan runtut bilangan decima/ke dalam deret biner yang disimpan dalam variabel $B$.

Sinyal yang berbentuk deret biner ini setelah mengalami pengolahan kemudian dikirimkan ke penerima. Pada sisi penerima, sinyal yang diterima diubah kembali ke dalam range -1 volt -1 volt. Pengubahan ini merupakan kebalikan dari proses sebelumnya yang diekspresikan dalam langkah - langkah matematis berikut:

$$
\begin{aligned}
& V_{r}=\operatorname{decimal}(B) \\
& V_{1}^{\prime}=V_{r} / 2^{n b i t-1} \\
& V_{0}^{\prime}=V_{1}^{\prime}-1
\end{aligned}
$$

Dengan $B$ merupakan deret biner yang diubah ke dalam bilangan decimal menggunakan operasi decima/ dan disimpan dalam variabel $V_{r}$. Kemudian hasil tersebut dibagi dengan level kuantisasinya ( $n$ bit) dan disimpan dalam variabel $V_{1}^{\prime}$. Hasil akhir adalah variabel $V_{0}^{\prime}$ yang merupakan pengurangan 1 dari variabel $V_{1}^{\prime}$. Sehingga didapat sinyal dalam rentang $-1-1$ volt.

\subsection{Modulasi Offset-QAM (O-QAM)}

Modulasi yang sering digunakan pada proses transmisi yaitu modulasi QAM dengan guard intervaldan Offset QAM (O-QAM). Gambar 2 menunjukkan adanya perbedaan antara modulasi QAM dan O-QAM, bit-bit pada posisi Inphase tetap pada posisi semula sedangkan terjadi offset atau pergeseran bit pada sisi Quadrature.
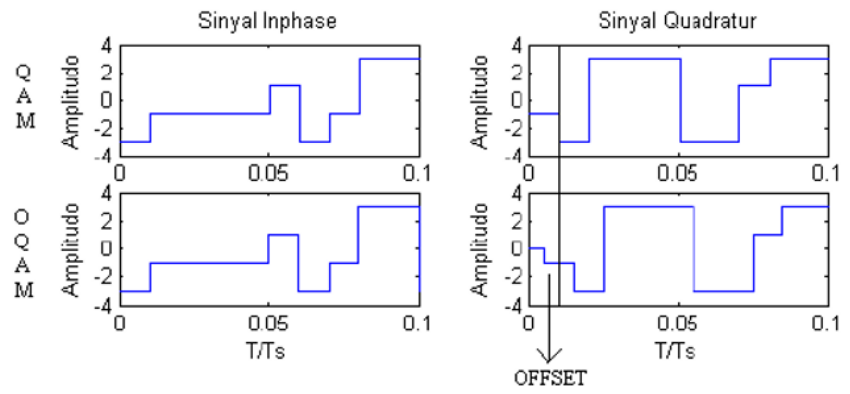

Gambar 2. Sinyal Modulasi pada QAM dan O-QAM 
Dengan skema O-QAM, spektrum kanal yang berdekatan terjadi overlap tanpa mengakibatkan crosstalk antar subcarrier yang dikarenakan penundaan setengah simbol waktu antara komponen Inphase dan Quadrature sinyal pada setiap subcarrier. Pada proses O-QAM terdiri dari dua tahap yaitu pra pengolahan O-QAM dan pasca pengolahan O-QAM.

\subsubsection{Pra Pengolahan O-QAM}

Blok pra pengolahan memanfaatkan perubahan antara simbol QAM dan O-QAM seperti ditunjukkan pada Gambar 3. Operasi pertama adalah pengubahan dari bilangan kompleks menjadi bilangan riil, di mana bagian riil dan imajiner dari simbol bernilai kompleks, dipisahkan lagi untuk membentuk dua simbol baru (operasi ini dapat disebut sebagai staggering). Urutan simbol-simbol baru ini tergantung pada nomor sub-channel. Operasi kedua adalah penggandaan demi urutan seperti pada Gambar 3 (Kansal \& Shankhwar, 2017).

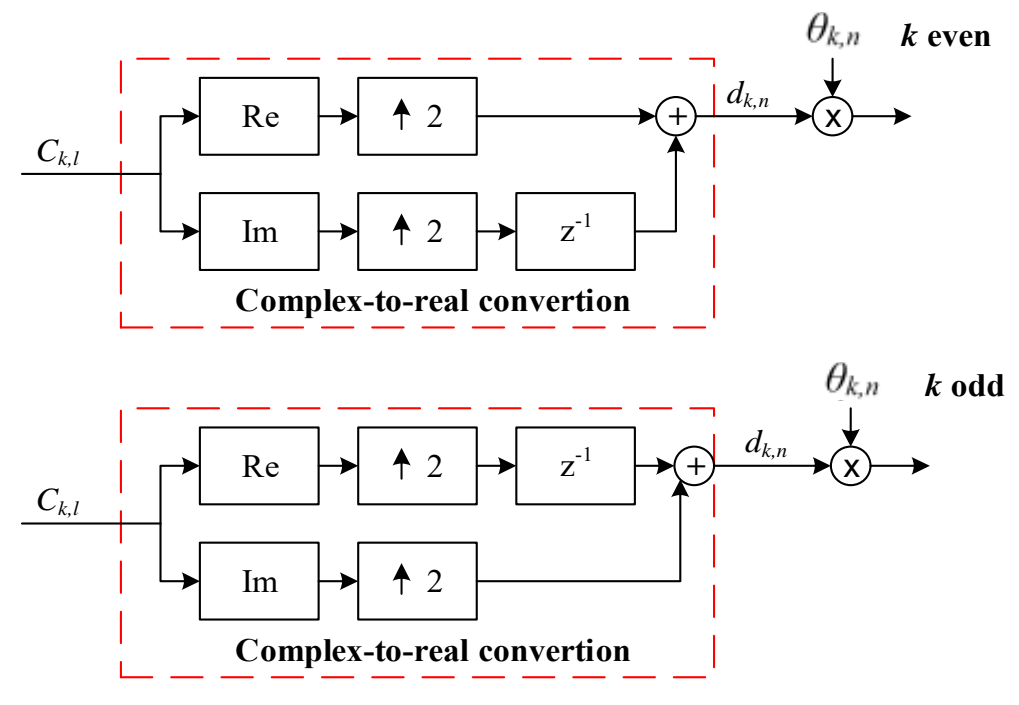

Gambar 3. Pra Pengolahan O-QAM

Setelah melalui tahap pengubahan bilangan kompleks ke riil, selanjutnya dikalikan dengan Persamaan (1) (Kansal \& Shankhwar, 2017):

$$
\theta_{k, n}=j^{(k+n)}
$$

Dengan j merupakan simbol imajiner, $\mathrm{k}$ adalah urutan kanal dan $\mathrm{n}$ adalah jumlah kanal. Namun, perlu diketahui bahwa tanda-tanda urutan dapat dipilih secara bebas, tetapi pola bilangan riil dan imajiner harus mengikuti Persamaan (1). Sebagai contoh, urutan alternatifnya dapat berubah menjadi (Kansal \& Shankhwar, 2017):

$$
\theta_{k, n}= \begin{cases}1, j, 1, j \ldots . & \text { untuk } k \text { genap } \\ j, 1, j, 1 \ldots . & \text { untuk } k \text { ganjil }\end{cases}
$$

\subsubsection{Pasca Pengolahan O-QAM}

Blok pasca pengolahan O-QAM merupakan kebalikan dari blok pra pengolahan O-QAM. Pasca pengolahan O-QAM seperti yang ditunjukkan pada Gambar 4, memiliki dua struktur yang sedikit berbeda tergantung pada nomor sub-channel. 


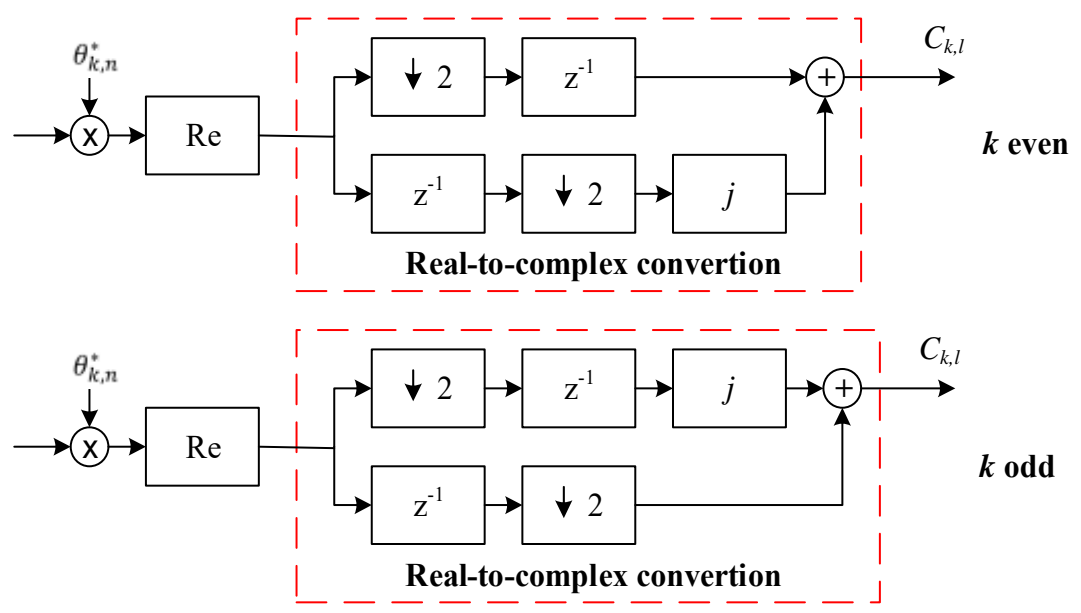

Gambar 4. Pasca Pengolahan O-QAM

Operasi pertama adalah perkalian dengan conjugate dari $\theta_{k, n}$ urutan yang diikuti oleh operasi mengambil bagian yang sebenarnya. Operasi kedua adalah konversi real-to-complex, di mana dua simbol bernilai riil berturut-turut (dengan satu dikalikan dengan j) membentuk simbol bernilai kompleks (operasi ini juga disebut sebagai de-staggering). Konversi riil ke kompleks menurunkan laju sampel dengan faktor 2 .

Operasi pertama adalah pengubahan bentuk kompleks menjadi riil. Di mana bagian riil dan imajiner dari simbol $C_{k, l}$ bernilai kompleks dipisahkan untuk membentuk dua simbol baru $d_{k, 21}$ dan $\mathrm{d}_{\mathrm{k}, 21+1}$. Urutan simbol-simbol baru ini tergantung pada nomor urut sub kanal. Pengubahan ini berbeda untuk sub-channe/ bernomor genap dan ganjil. Fungsi pengubahan bilangan kompleks menjadi bilangan riil digunakan meningkatkan laju sampel sebesar 2 kali. Operasi kedua adalah perkalian dengan $\theta_{k, n}$.

\subsection{Filter Bank Multi Carrier (FBMC)}

FBMC terdiri dari 2 proses di dalamnya yaitu pra pemrosesan dan pasca pemrosesan. Proses pada pra pemrosesan di FBMC bernama sintesis bank filter. Sedangkan pada pasca pemrosesan disebut sebagai analisis bank filter. Sintesis bank filter diletakkan pada proses pengiriman data tepatnya sesudah proses pra pengolahan O-QAM. Sedangkan di sisi penerima proses analisis berada sebelum proses pasca pengolahan O-QAM. Adapun proses di dalam filter bank ditunjukkan pada Gambar 5 dan 6.

Berdasarkan Gambar 5 sintesis bank filter terdiri dari 2 proses yaitu proses IFFT dan proses filter. Filter pada sintesis bank filter digunakan untuk memisahkan sinyal berdasarkan frekuensinya. Jenis filter yang digunakan pada sintesis bank filter dapat menggunakan berbagai jenis filter. Jenis filter yang paling mudah adalah filter ideal. Konsep pada filter ideal adalah frekuensi yang ada akan langsung diteruskan atau diloloskan tanpa adanya peredaman.

Berdasarkan Gambar 6, analisis bank filter terdiri dari 2 proses yaitu proses FFT dan proses filter. Filter pada analisis bank filter digunakan untuk menggabungkan sinyal berdasarkan frekuensinya. Jenis filter yang digunakan pada analisis bank filter harus sesuai dengan jenis filter yang digunakan pada proses sintesis bank filter. 


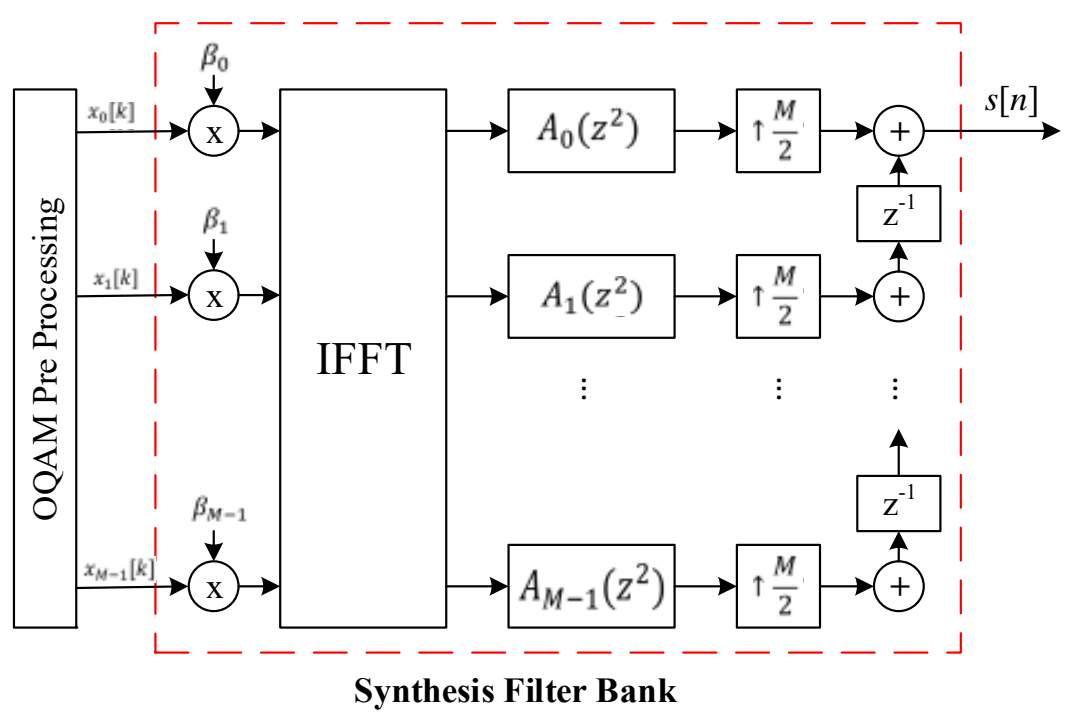

Gambar 5. Konfigurasi pada Sintesis Bank Filter

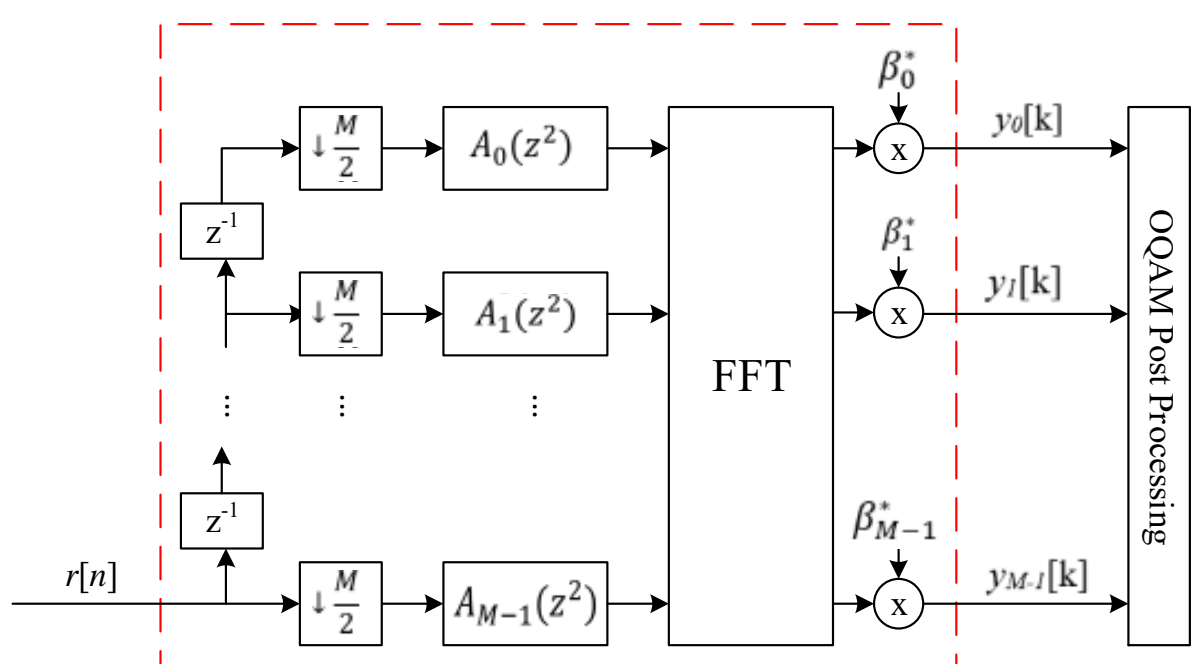

Analysis Filter Bank

Gambar 6. Konfigurasi pada Sintesis Bank Filter

\subsection{Equalization}

Proses equalization merupakan proses mencari respon agar kanal dapat diatasi. Pada proses estimasi kanal maka akan didapatkan matrik respon kanal. Equalizer sering digunakan dalam domain waktu maupun domain frekuensi dalam sistem komunikasi tradisional. Equalizer pada domain waktu, yaitu dalam sistem FDM tradisional pemerataan atau ekualisasi tentunya sangat diperlukan. Karena equalizer ini digunakan sebagai penyeimbang dari karateristik kanal. Pada bagian penerima, equalizer menghasilkan karakteristik yang berlawanan dari kanal untuk mengimbangi ISI akibat waktu yang bervariasi dari kanal multi-path. Namun equalizer dalam domain frekuensi merupakan suatu teknik penting yang digunakan untuk mengurangi ICI pada estimasi kanal. Hal ini disebabkan karena pengaruh dari sisa frekuensi offset dan efek pergeseran dari doppler terutama pada channe/yang berubah cepat. 
Jenis - jenis variasi ekualisasi yang akan digunakan pada penelitian ini adalah sebagai berikut:

a. Zero Forcing (ZF)

Zero Forcing (ZF) adalah merupakan jenis equalizer atau algoritma deteksi simbol yang paling sederhana. Penggunaan algoritma ini cukup mudah yaitu dengan $\mathrm{H}$ adalah suatu matriks kanal dan $\mathrm{W}$ adalah matriks yang merepresentasikan proses linier pada penerima, sehingga pada ZF harus memenuhi syarat (Hidayat et al., 2011).

$$
W H=1
$$

Agar setiap elemen yang diinginkan dari simbol data dapat dideteksi, maka diperlukan adanya proses "memaksa" interferensi menjadi nol. Matriks W merupakan matriks kebalikan atau kebalikan semu (pseudo invers, PI) dari matriks kanal $\mathrm{H}$, seperti ditunjukkan pada persamaan berikut (Hidayat et al., 2011):

$$
\begin{gathered}
W_{Z F}=H^{-1} \quad \text { untuk } N_{T x}=N_{R x} \\
W_{Z F}=\left(H^{H} H\right)^{-1} H^{H} \quad \text { untuk } N_{T x} \neq N_{R x}
\end{gathered}
$$

Dengan $\mathrm{H}^{\mathrm{H}}$ merupakan konjugat transpos matriks $\mathrm{H}$. Pseudo Invers (PI) ada apabila jumlah antena pengirim ( $\left.\mathrm{N}_{\mathrm{TX}}\right)$ lebih kecil atau sama dengan jumlah antena penerima $\left(\mathrm{N}_{\mathrm{Rx}}\right)$, sedangkan untuk $\mathrm{N}_{\mathrm{Tx}}$ yang lebih besar dari $\mathrm{N}_{\mathrm{Rx}}$, maka $\mathrm{H}^{\mathrm{H}} \mathrm{H}$ bernilai singular sehingga kebalikannya tidak terdefinisi.

\section{b. bandwidth (MMSE)}

Minimum Square Square Error (MMSE) adalah skema estimasi yang meminimalkan mean square error dan digunakan untuk proses estimasi kualitas. Skema ini tidak sepenuhnya menghilangkan inter symbol interference (ISI) tetapi mengurangi atau meminimalkan komponen derau dan ISI pada output. MMSE menemukan koefisien M yang meminimalkan kriteria

$$
E\left\{[M y-x][M y-x]^{H}\right\}
$$

Pada pemecahan kriteria di atas, nilai matematika M keluar menjadi

$$
M=\left[H^{H} H+N_{0} I\right]^{-1} H^{H}
$$

dari persamaan di atas jelas bahwa persamaan ini berbeda dari persamaan Zero Forcing equalizer berdasarkan nilai $\mathrm{NoI}$. Jika dberikan nilai $=0$ dalam persamaan tersebut maka MMSE equalizer akan menjadi Zero Forcing equalizer. Metode ini dapat diperluas ke beberapa konfigurasi antena transceiver (Ebinowen, Abdulrazak, \& Tijani, 2018). Keuntungan menggunakan MMSE equalizer adalah kompleksitas komputasi yang lebih rendah dibandingkan dengan ekualizer lainnya hanya jika panjang filter MMSE equalizer lebih kecil dari panjang respon impuls channel. MMSE memiliki kinerja bit error rate (BER) optimal untuk panjang blok panjang pada SNR tinggi.

Ekualisasi MMSE menggambarkan pendekatan untuk meminimalkan nilai Mean Square Error(MSE), yang merupakan ukuran umum untuk pengukuran kualitas. Fitur utama dari equalizer MMSE adalah tidak menghilangkan ISI seluruhnya tapi meminimalkan total daya derau dan komponen ISI pada output. MMSE Equalizer memiliki kinerja yang lebih bagus dibandingkan Zero Forcing karena tidak hanya menekan ISI tetapi juga meminimalkan daya derau. 


\subsection{Bit Error Rate (BER) dan Symbol Error Rate (SER)}

Pada simulasi ini, BER dihitung dengan membandingkan sinyal hasil demodulasi di sisi penerima dengan sinyal masukan (input). Sedangkan SER dihitung dengan membandingkan simbol 16-QAM yang diterima di sisi penerima dengan simbol keluaran pemeta 16-QAM yang dikirim. Prinsip kerja perhitungan BER secara umum merupakan fungsi ketidaksamaan antara dua bit, dan jika hasil ketidaksamaan tersebut bernilai 1 maka terdapat satu bit yang salah. Perhitungan nilai BER ini dilakukan untuk keseluruhan bit yang dibangkitkan di sisi pengirim terhadap keseluruhan bit di sisi penerima.

Pada dasarnya nilai BER sebanding dengan nilai SER atau dengan kata lain semakin besar nilai SER maka BER juga akan semain besar. Hubungan antara SER dan BER berkaitan dengan nilai dari level modulasi sistem $M$-ary yang digunakan. Sebagai contoh pada simulasi ini digunakan sistem M-ary QAM dengan M = 16 (sistem 16-QAM), maka pendekatan perbandingan antara SER dan BER berdasarkan Persamaan (14) akan menjadi:

$$
\begin{aligned}
& \frac{1}{M} \leq \frac{P_{B}}{P_{S}} \leq \frac{M / 2}{M-1} \\
& \frac{P_{B}}{P_{S}} \leq \frac{16 / 2}{16-1} \leq \frac{8}{15} \\
& P_{S} \leq \frac{15}{8} P_{B}
\end{aligned}
$$

Sebagaimana terlihat pada persamaan tersebut bahwa nilai $P_{S}$ atau SER akan lebih besar dibanding dengan $\mathrm{P}_{\mathrm{B}}$ atau BER. Hal ini disebabkan karena tidak semua bit pada simbol yang salah akan bernilai salah atau memunculkan galat. Sebagai contoh pada sistem 16-QAM, setiap simbol akan merepresentasikan 4 bit dan apabila ada 1 simbol yang salah maka belum tentu ke-4 bit tersebut juga akan salah. Dapat disimpulkan bahwa apabila kesalahan simbol mendekati $100 \%$ maka kesalahan bit akan lebih kecil dari $100 \%$.

\section{HASIL SIMULASI DAN ANALISIS}

Sinyal yang ditunjukkan oleh Gambar 7 merupakan sinyal input yang berupa sinyal audio dalam bentuk *.wav yang digunakan dalam simulasi dengan jumlah titik sebanyak 2048 titik atau sekitar 0,012 detik. Sinyal tersebut menunjukkan adanya fluktuasi nilai yang acak sehingga sesuai untuk simulasi yang akan dijalankan.

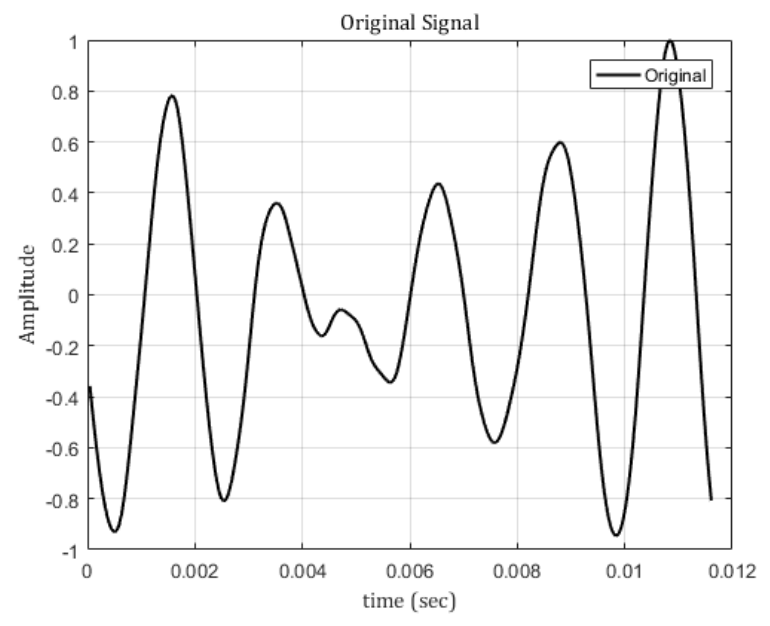

Gambar 7. Sinyal Audio yang Dikirimkan 


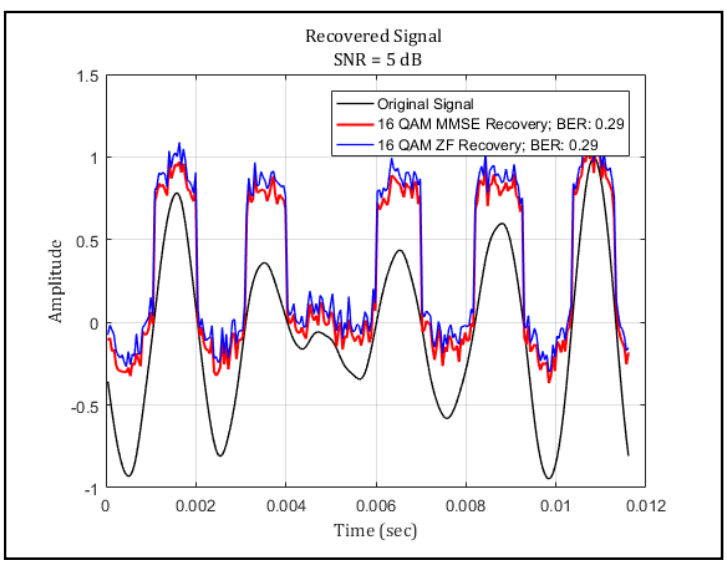

(a)

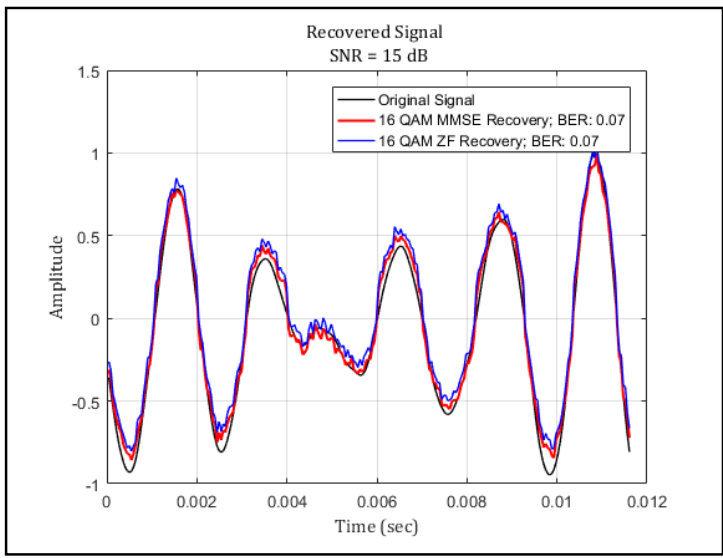

(c)

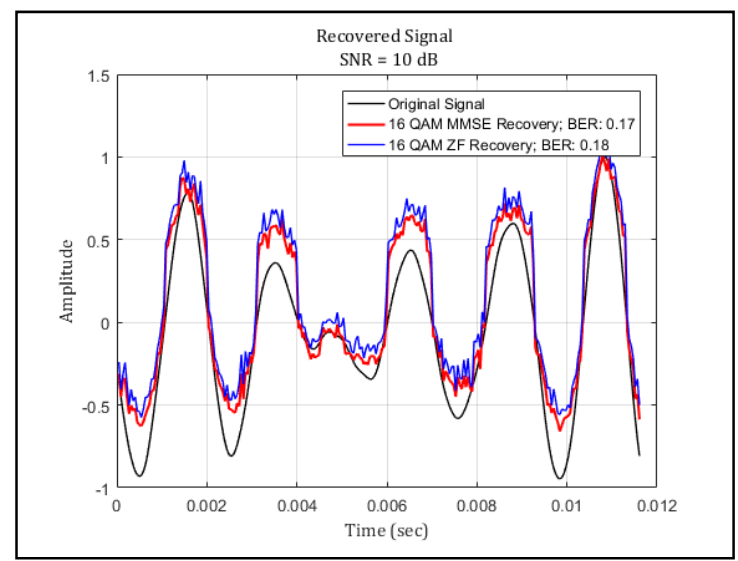

(b)

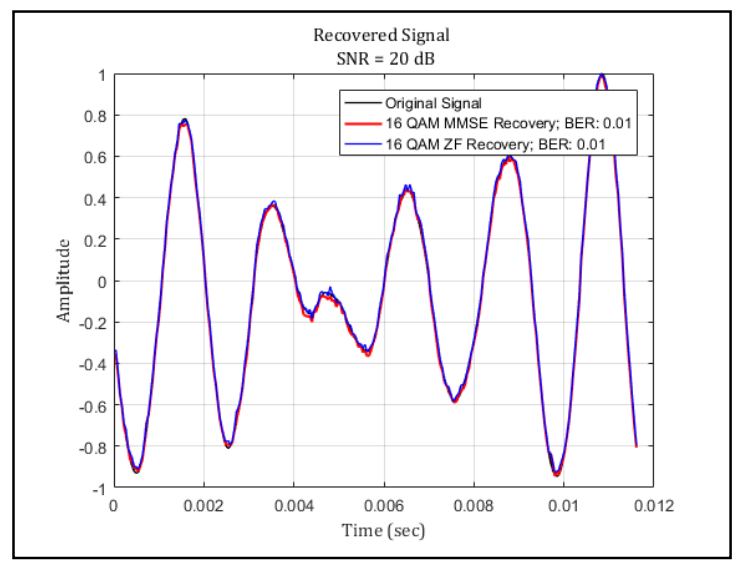

(d)

Gambar 8. Sinyal Terima dengan Variasi SNR: (a) $5 \mathrm{~dB}$; (b) $10 \mathrm{~dB}$; (c) $15 \mathrm{~dB}$; (d) $20 \mathrm{~dB}$

Berdasarkan hasil pengujian secara simulasi maka didapatkan data sinyal terima yang diukur berdasarkan SNR yang diberikan yakni sebesar $5 \mathrm{~dB}, 10 \mathrm{~dB}, 15 \mathrm{~dB}$ dan $20 \mathrm{~dB}$ sebagaimana ditunjukkan pada Gambar 8. Sinyal terima ini diukur pada saat SNR yang diberikan berbedabeda. Hal ini dimaksudkan untuk mengetahui pengaruh SNR yang diberikan terhadap sinyal terima yang dihasilkan. Hasilnya menunjukkan bahwa saat SNR bernilai $5 \mathrm{~dB}$ maka sinyal yang diterima sangat berbeda dengan sinyal audio yang ditransmisikan. Sedangkan saat SNR mempunyai nilai yang besar yakni $20 \mathrm{~dB}$ maka sinyal yang dterima mirip dengan sinyal yang dikirimkan. Hal ini karena daya derau pada SNR 20 dB lebih kecil dibandingkan dengan daya sinyal.

Pada simulasi sistem FBMC-Offset QAM ini, data yang diterima di sisi penerima merupakan hasil dari perkalian sinyal kirim dengan kanal lalu ditambahkan dengan derau, dengan penambahan ekualizer di dalamnya yakni Zero Forcing dan MMSE. Perbandingan kinerja BER dari hasil simulasi ditunjukkan pada Gambar 9. Berdasarkan gambar tersebut dapat ditunjukkan bahwa penggunaan ekualisasi jenis MMSE pada sistem FBMC-Offset QAM mempunyai hasil yang lebih baik yakni nilai BER yang lebih kecil dibandingkan dengan penggunaan ekualisasi jenis Zero Forcing. Sebagaimana yang ditunjukkan pada grafik di Gambar 9 bahwa saat SNR 5 dB maka BER untuk ZF sebesar 0,2941 sedangkan BER untuk MMSE sebesar 0,2875. Hasil ini menunjukkan bahwa kinerja MMSE untuk parameter BER lebih baik dibanding ZF. Hal ini dikarenakan pada ekualisasi MMSE, selain kompensasi kanal juga 
ada proses kompensasi derau (No) seperti pada Persamaan (13), sedangkan di ekualisasi ZF tidak ada kompensasi derau seperti yang diperlihatkan oleh Persamaan (11) sementara dalam penelitian ini kehadiran derau diperhitungkan. Hasil perbandingan kinerja BER sebanding dengan hasil perbandingan kinerja SER sebagaimana ditunjukkan pada Gambar 10, yakni nilai SER untuk ZF sebesar 0,5514 dan untuk MMSE sebesar 0,5391. Hal ini dikarenakan nilai $P_{s}$ (probabilitas kesalahan simbol atau symbol error ratio, SER) berbanding lurus dengan $\mathrm{P}_{\mathrm{B}}$ (probabilitas kesalahan bit atau bit error ratio, BER) sebagaimana ditunjukkan pada Persamaan (16).

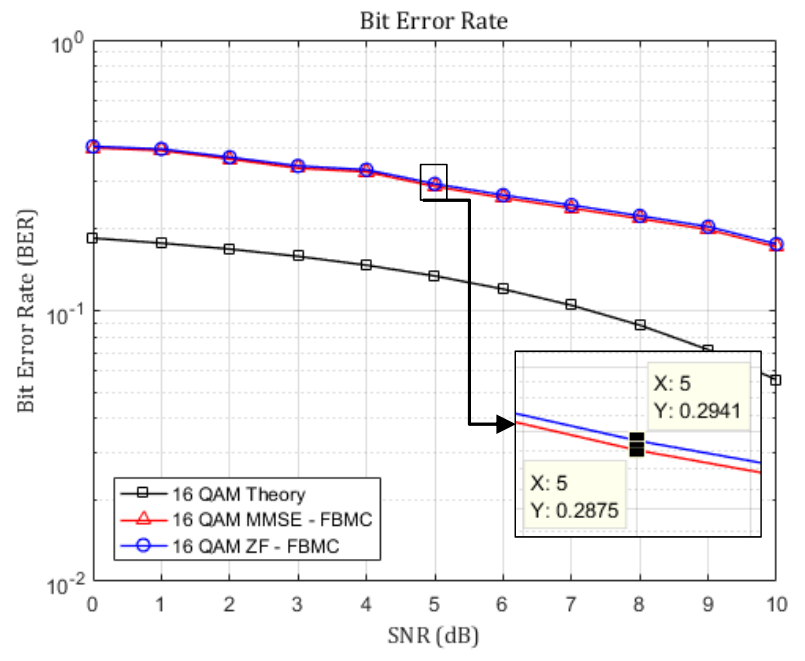

Gambar 9. Perbandingan BER pada FBMC-Offset QAM menggunakan ZF dan MMSE

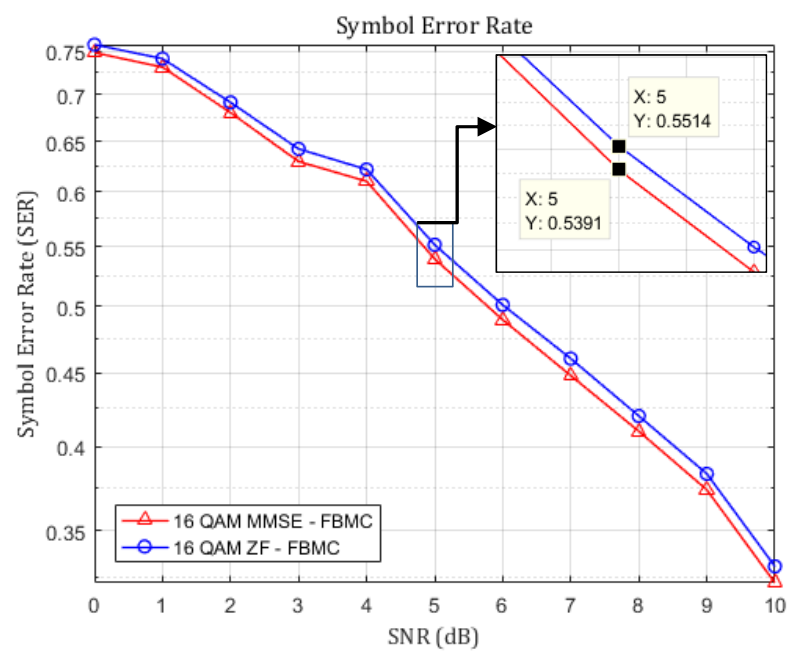

Gambar 10. Perbandingan SER pada FBMC-Offset QAM menggunakan ZF dan MMSE

Perbandingan kapasitas kanal pada sistem FBMC-Offset QAM yang menggunakan Zero Forcing dan MMSE dapat dilihat pada Gambar 11. Kinerja sistem FBMC-Offset QAM berdasarkan parameter kapasitas kanal pada simulasi ini menunjukkan bahwa kapasitas kanal sistem yang menggunakan ekualisasi MMSE lebih besar yakni $0,9433 \mathrm{~b} / \mathrm{s} / \mathrm{Hz}$ dibanding sistem yang 
menggunakan ekualisasi Zero Forcing yakni sebesar $0,8891 \mathrm{~b} / \mathrm{s} / \mathrm{Hz}$. Namun dari hasil yang didapat tersebut masih di bawah kapasitas kanal secara teori yakni sebesar 1,37 b/s/Hz.

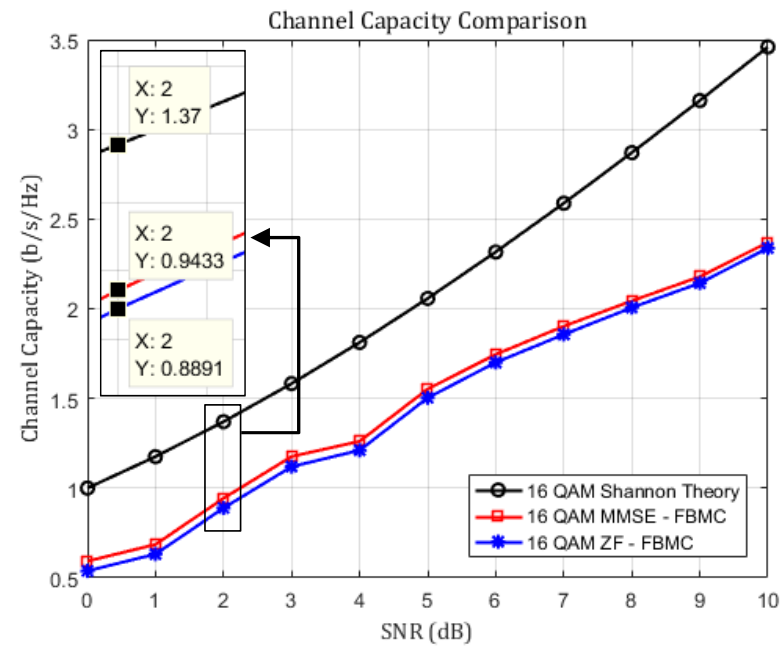

Gambar 11. Perbandingan kapasitas kanal FBMC-Offset QAM menggunakan ZF dan MMSE

\section{KESIMPULAN}

Berdasarkan hasil simulasi dapat disimpulkan bahwa kinerja sistem FBMC-Offset QAM yang menggunakan ekualisasi MMSE lebih baik dibanding ekualisasi Zero Forcing dalam kinerja parameter bit error rate (BER), symbol error rate (SER) dan kapasitas kanal. Nilai BER dan SER untuk ekualisasi MMSE lebih kecil dibanding ekualisasi Zero Forcing. Dengan demikian, kinerja sistem ini memiliki performa lebih baik jika menggunakan ekualisasi MMSE. Kesimpulan tersebut dikuatkan lagi dengan nilai kapasitas kanal dari MMSE yang lebih besar dibanding Zero Forcing. Berdasarkan hasil tersebut maka ekualisasi MMSE akan lebih tepat digunakan dalam sistem ini sebagai kompensasi jika diasumsikan sistem berisiko akan gangguan derau.

\section{DAFTAR RUJUKAN}

Baltar, L. G., \& Nossek, J. A. (2012). Multicarrier systems: a comparison between filter bank based and cyclic prefix based OFDM. OFDM 2012; 17th International OFDM Workshop 2012 (InOWo'12), 1-5. VDE.

Blel, I., \& Bouallegue, R. (2015). Spatial Multiplexing OFDM/OQAM Systems With Time Reversal Technique. International Journal of Wireless \& Mobile Networks, 71 ), 43-54. https://doi.org/10.5121/ijwmn.2015.7103

Ebinowen, T. D., Abdulrazak, Y. K., \& Tijani, B. O. (2018). Optimization of MIMO System Using SIC-MMSE in AWGN Rayleigh Fading Channels. International Journal of Engineering $\begin{array}{llll}\text { Sciences } \& \text { Research Technology, 146-153. } & \text { 79), }\end{array}$ https://doi.org/10.5281/zenodo.1411110 
Hidayat, R., Isnawati, A. F., \& Setiyanto, B. (2011, December 7). Channel Estimation in MIMOOFDM Spatial Multiplexing Using Least Square Method. Presented at the International Symposium on Intelligent Signal Processing and Communication Systems (ISPACS), Chiang Mai, Thailand. https://doi.org/978-1-4577-2166-3

Kansal, P., \& Shankhwar, A. K. (2017). FBMC vs OFDM Waveform Contenders for 5 G Wireless Communication System. Wireless Engineering and Technology, 08(04), 59-70. https://doi.org/10.4236/wet.2017.84005

Kaur, S., Kansal, L., Gaba, G. S., \& Safarov, N. (2018). Survey of Filter Bank Multicarrier (FBMC) as an efficient waveform for 5G. International Journal of Pure and Applied Mathematics, $118(7), 45-49$.

Kumar, A., \& Gupta, M. (2015). A Novel Modulation Technique for 5G Mobile Communication System. American Journal of Applied Sciences, 12(9), 601-605. https://doi.org/10.3844/ajassp.2015.601.605

Medjahdi, Y., Terre, M., Le Ruyet, D., Roviras, D., Nossek, J. A., \& Baltar, L. (2009). Inter-cell interference analysis for OFDM/FBMC systems. 2009 IEEE 10th Workshop on Signal Processing Advances in Wireless Communications, 598-602. IEEE.

Nedic, S., \& Vallet, R. (2010). Power and spectral efficiency advantages of OFDM/OQAM over OFDM/QAM for PHY in wireless and Cognitive Radio networks. ${ }^{T E L} F O R$ 2010, Belgrade, Serbia.

Siohan, P., Siclet, C., \& Lacaille, N. (2002). Analysis and design of OFDM/OQAM systems based on filterbank theory. IEEE Transactions on Signal Processing, 50(5), 1170-1183. 